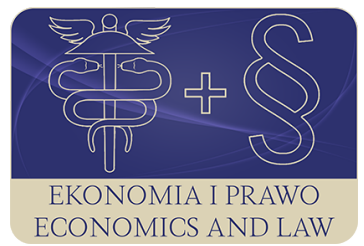

EKONOMIA I PRAWO. ECONOMICS AND LAW

Volume 16, Issue 2, June 2017

p-ISSN 1898-2255, e-ISSN 2392-1625

www.economicsandlaw.pl

ORIGINAL ARTICLE

received 13.06.2017; revised 25.06.2017; accepted 30.06.2017

Citation: Dziemianowicz, R. (2017). Tax administrative costs as a component of tax transaction costs in Poland and other OECD countries. Ekonomia i Prawo. Ecomomics and Law, 16(2): 123-140. doi:10.12775/EiP.2017.009.

\title{
Tax administrative costs as a component of tax transaction costs in Poland and other OECD countries
}

\author{
RYTA DZIEMIANOWICZ \\ University of Bialystok, Faculty of Economics and Management, Department of Treasury, \\ ul. Warszawska 63, 15-062 Białystok, Poland \\ $\square$ r.dziemianowicz@uwb.edu.pl
}

\begin{abstract}
Motivation: While implementing a tax policy, attention should be paid not only to the amount of tax revenues but also to the total cost of the fiscal process itself. Only an analysis with consideration of tax collection costs provides the possibility of unequivocal assessment of a tax system's effectiveness.

Aim: The aim of the article is to identify the elements of tax transaction costs and to analyze in detail the tax administrative costs, as well as to assess the effectiveness of the Polish tax system compared to that of other OECD countries.

Results: The Polish tax administration is one of the most expensive in the European Union and it requires reforms. According to the OECD, tax collection costs in Poland in 2013 amounted to $1.6 \%$ of tax revenues. Among the 56 countries surveyed by the OECD, only Japan (1.74\% of revenue) and Saudi Arabia (1.62\%) had a higher tax collection costs index.
\end{abstract}

Keywords: administrative costs of taxation; fiscal policy; effectiveness of the tax system; tax administration

JEL: H2O; H2l; H26; H30

\section{Introduction}

A modern state has a fiscal character. This is primarily due to the progress of the public sector observed in the 20th and 2lst century and, as a result, an increase in its operating costs. In fact, a state disposes of its own revenue (e.g. 
property) to a limited extent and it is primarily 'dependent' on taxes, which are the main source of public revenue. The high level of fiscality, as rightly said by Schumpeter, 'suppresses entrepreneurship' (Glapiński, 2003, p. 25); it contributes to the lowering of investments and production, as well as a limitation of consumption. It distorts economic decisions and results in the generation of costs, both for individuals, consumers and producers, as well as the society. At the same time, it leads to avoiding certain behaviors, or even evading tax obligation and transition to the gray economy. Thus there is a limit to the increase in tax burdens, which can also be defined as the limit of state fiscal capacity beyond which public revenue no longer rises, despite increasing the tax rates. Under these circumstances, one of the possibilities to obtain additional tax revenue remains the strive to increase the efficiency of the tax system.

The state, through the implementation of its tax policy, should turn its attention not only to the amount of tax revenue in gross values but also to the macroeconomic balance. Particularly important are the relations between the sum of social benefits, which are the result of its activity, and the sum of costs of the fiscal process itself. For obvious reasons the tax transaction costs should not be higher than tax revenues. Otherwise, when the costs exceed the benefits, the whole fiscal process on the macro scale loses its economic and social meaning. The analysis of gross tax revenue, without taking such costs into account, does not allow an unequivocal evaluation of tax system efficiency.

The purpose of the article is to identify the elements of tax transaction costs, as well as a detailed analysis of one of them, i.e. the tax administrative costs, listed among the so-called tax collection costs (also referred to as operational costs). The study also attempts to assess the fiscal effectiveness of the Polish tax system against other OECD countries, which is directly related to the tax system's performance of the fiscal function. This effectiveness is defined in this article as a ratio of the fiscal efficiency of taxes collected over a period of time and the tax administration costs incurred directly by the public sector. The analysis omits a significant element of the tax administration cost, i.e. the costs incurred by taxpayers, namely the private sector, which is a kind of simplification of the measurement.

\section{Research methods}

The assessment of the fiscal effectiveness of the Polish tax system was made on the basis of analysis of literature devoted to theory of tax transaction costs, which made it possible to identify individual elements, separate tax administrative costs and determine their role in shaping tax revenue and fiscal effectiveness of the tax system. The study adopts the descriptive method with elements of statistical data analysis. The analysis includes selected OECD member states. It was assumed that the tax (fiscal) efficiency ratio, in contrast to the economic efficiency of taxation primarily relating to the quality of taxes, allows to assess tax system efficiency. 
It should be emphasized, however, that fiscal efficiency refers not only to productivity but also to tax cheapness. It was tested using a measure determining the share of tax administration costs borne by the public sector in revenue from all taxes within a given period. Data on tax debt due were additionally used to assess tax administration effectiveness. The study made it possible to verify the hypotheses formulated as follows: The costs of functioning of the tax administration in Poland are high but this does not contribute to increasing the efficiency of tax collection. The fiscal effectiveness of the Polish tax system is relatively lower than in other OECD countries.

The paper uses the OECD report entitled Tax Administration 2015 (2015)1, which analyzes data on the operating costs of tax administration functioning in 56 countries (including several non-OECD ones). The statistical data contained in this study come from official national reports or have been provided by individual tax administrations. They mainly concern three categories of costs: administration, salaries and IT expenses ${ }^{2}$. These are the total costs of tax administration. The report does not include expenses related to the costs of making and enforcing tax law (e.g. expenditures on the work of the parliament, government, courts for tax offenses, etc.).

\section{The essence of the fiscal process costs}

The feature that distinguishes the costs among other categories is that they are borne for a specific purpose. A simple definition of costs is provided by the dictionary of the Polish language: a sum of money spent on the purchase or payment of something (Stownik Języka Polskiego, 2017); clearly they are measurable here. In literature, however, depending on the current of the economy, their content is interpreted variously. A common feature of the particular definitions is undoubtedly the reduction of economic benefits. In accounting, costs borne by entities represent a reduction in tangible economic benefits in the form of a reduction in the value of assets or an increase in the value of liabilities and reserves. Neoclassical economics uses the concept of economic costs as the sum of accounting costs and alternative costs that relate to lost opportunities/benefits. On the other hand, new institutional economics (NEI) uses the term transaction costs, which are partly uncountable and intangible. NEI has not developed a uniform definition of this concept, yet all examples quoted in the reference literature emphasize their non-production origins and institutional place of creation (Zbroińska, 2011, pp. 43-46). At the same time, economists agree that transaction costs always have to do with transactions, transfers

1 The OECD publishes reports on this issue every two years starting from 2007. Despite some reservations about the data contained therein relating to different jurisdictions and different regulatory regimes, they allow for simplified international comparisons.

${ }^{2}$ IT - understood as expenses related to the purchase of technologies for the collection, processing, transmission, storage, security and presentation of information, including e-declarations and e-tax returns. 
of property rights and the institutional system ${ }^{3}$. Zbroinska (2013, pp. 165-166) mentions the following as special features of transaction costs: frequent ignorance of their existence, difficulties in quantification, omitting in the economic account, treatment as a side effect of transactions and transfer of property rights. According to NEI principles, transaction costs are always present when certain activities are regulated by formal or informal institutions. They are part of the operating costs, 'thus having an impact on the effectiveness of the choices made and being evaluated on the basis of the minimization criterion, like other costs' (Zbroińska, 2009, p. 100).

The definitions of economic and transactional costs is linked by the category of non-received/lost revenue. 'Economic costs, in their non-measurable part (relating to alternative costs), (...) express an abstract loss of benefits resulting from the choice of a given utilization of capital compared to a rejected alternative. In NEI, lost inflows are the result of disloyalty of the persons/parties breaking the rules. Methodological problems result in this part of transaction costs not being included in the accounting of units, despite the impact on the business results. Only the measurable elements of transaction costs are reflected in the accounting records in the form of resource consumption' (Zbroińska, 2011, p. 45).

Transaction costs can be a universal measure of efficiency in all institutions (Williamson, 1998, p. 390), including those of the tax system. In Zbroińska's opinion, they can supplement the theory of optimal taxation, especially in the aspect of the additional criterion for choosing the optimal tax system.

The theory of optimal taxation does not expose the fiscal purpose of taxes as the main goal. Researchers are still primarily focused on the issue of the efficiency of taxation. It is assumed that tax receipts are known (in advance), therefore, to increase public revenue in this regard, a more effective tax system should be found which will minimize the losses resulting from imposing a tax. 'The main idea of this theory holds a clear practical message: every tax reform should be preceded by an analysis of fiscal benefits and losses resulting from the imposition of new taxes or changes in existing ones. Therefore, it is also important to analyze the costs of the fiscal process' (Dziemianowicz, 2007, p. 105).

In both of these theories, it is assumed that the costs associated with the imposition of taxes are minimized, but this is interpreted differently in each one. The source of ineffectiveness of the NEI tax system is the transaction costs associated with the institutions which impose and collect taxes. The theory of optimal taxation, however, assumes that tax collection can only be justified when the utility of public goods and redistributive effects are higher than social losses (welfare losses) resulting from the imposition of taxes (excess burden

${ }^{3}$ Institutional system means a system/arrangement of institutions understood as a set of standards and principles that exert a significant influence on the attitudes of society members. 'Institutional system encompasses the interdependence between the diverse elements of society and the economy, which, despite the lack of homogeneity, is a functional whole' (more in Gruszewska (2012, pp. 63-64)). 
of taxation). In this case, the source of ineffectiveness are distortions caused by the substitution effect of taxes. At the same time, the aim of both these theories is: 'searching for the best solutions, assuming the limitations on which they are both based: accepting a priori the function of welfare and the relation of transaction costs with the functioning and changing of institutions' (Zbroinska, 2009, p. 104).

\section{Classification of tax transaction costs}

The imposition of taxes is a transfer of resources from the private to the public sector. Under a contract concluded between a state and a citizen, the citizen in exchange for paid taxes receives protection of rights and institutional and legal order (Hockuba, 1995, p. 73). The conclusion and execution of this contract generate costs, both on the part of individual units, consumers and manufacturers, as well as the society. On the one hand, taxes affect the economy, distort price relations developed in the market, and thus, as Grądalski (2006, p. 83) argues, deform market economic rationality. As a result of the imposition of tax, consumers lose part of consumption, while manufacturers reduce employment and sales. It can therefore be said that they affect the effectiveness of the activities undertaken. On the other hand, tax collection (enforcement) itself generates costs, both on the part of the state, primarily relating to the activities of the tax administration, and on the part of taxpayers. In this case, they arise from the need to comply with applicable regulations and meet the tax obligations imposed but also from striving, within the limits of the law, to minimize tax liabilities. These two major cost categories together make up the fiscal process costs, which Olivier and Bartley (2005) call tax transaction costs (scheme $1)$.

Scheme 1 shows a simplified division of tax transaction costs. Not all of the above-mentioned components are fully measurable. Probably the highest value in this set is represented by the costs related to loss of effectiveness/welfare (excess burden of taxation). These are the consequences of imposing any tax. The cause of additional losses resulting from the imposition of taxes is the need for taxpayers to adjust to the changes in the price ratios resulting from taxation. In the reference literature, the term 'deadweight loss of taxation' is used alternatively when referring to loss of welfare/effectiveness resulting from the imposition of a tax. It reflects the defined concept well, as taxes reduce the revenues being at the disposal of taxpayers, thereby reducing their consumption, investment and savings opportunities but also reducing state revenue.

The costs related to loss of welfare/effectiveness are invisible and difficult to quantify. However, even the estimation of the deadweight loss of taxation provides some important information. First and foremost, it allows to compare the private and public costs of various tax options in terms of fiscal efficiency. However, their measurement in individual countries is not the subject of systematic research. Economists first began to estimate the cost of welfare loss 
in the 1960s. A. Harberger, who is considered a pioneer of research in this field, initially estimated that e.g. income taxes reduce the readiness of Americans to take up a job by $5-11 \%$, and the additional welfare loss resulting from their imposition amounts to approx. $2.5 \%$ of tax revenues in this respect ${ }^{4}$. Contemporary estimates of the excess burden of taxation are much higher and at the same time vary depending on the author. Economists estimate that welfare losses resulting from the application of a tax are high. On the basis of American studies, it can be stated that their estimated share in general tax revenues may even range from $18 \%$ to $24 \%$. However, taking into account the lack of uniform measurement methods and the varied legal solutions that exist in different jurisdictions, it can be assumed that these estimates can be very different. For example, Grądalski (2006, pp. 98-99), partly using American research ${ }^{6}$, calculated that in Poland the imposition of an additional one zloty of tax generates a loss in the private sector amounting to PLN $1.30^{7}$. Assuming that the delivered public goods and services at least partly compensate for the loss of welfare in the private sector ${ }^{8}$, he concluded that amount of the marginal net loss of welfare for each additional zloty of tax was approximately PLN 0.30. According to Grądalski (2006, pp. 98-99), the loss of welfare in Poland in 2002, resulting from the growth of fiscality, amounted to $2.4 \%$ of total tax revenue.

The second major category of tax transaction costs are the broadly understood tax collection costs, which consist of tax administrative costs and tax compliance costs. Administrative costs are the costs borne by the public sector in connection with the establishment and collection of taxes, primarily relating to the functioning of tax administration. They are strictly connected with taxes (aimed at collecting them). If not for the fact of imposing taxes, such costs would not be incurred. Similarly, the costs of adjusting taxpayers are private sector costs incurred by taxpayers in connection with their obligations under tax laws (Sandford et al., 1989, pp. 3-10).

Evans (2001, pp. 5-9) refers to the costs related to tax collection as operational costs, and defines them as the sum of costs related to tax collection administration and the costs related to compliance with the taxes incurred by taxpayers. He clearly emphasizes their direct character. Evans also draws attention to the indirect costs incurred by taxpayers in connection with their imposition, which include, for example, conscious actions leading to a reduction

4 More in Dziemianowicz (2007).

5 More in Robson (2005).

${ }^{6}$ F. Grądalski (2006) uses the research of C.L. Ballard et al. (1985, pp. 128-138), who, at a given fiscal level, amounting to 30\% in 1980, estimated that a 1 USD tax increase would result in an additional loss of 0.33 USD. He assumes that the scale of fiscality in Poland is about $45 \%$, while the additional loss in welfare resulting from taxation is PLN 0.30 .

7 The data concern 2002.

${ }^{8}$ More in Pedersen et al. (2013). 
in sales. However, he rather qualifies them to the welfare loss category (Evans \& Tran-Nam, 2014, p. 7).

It should be emphasized that there is no uniform definition of tax collection administrative costs in reference literature. Individual researchers include different expenditures, which makes it difficult to accurately estimate them and make international comparisons. The problem can be, for example, the costs of lawmaking or the court costs associated with the tax administration's running of tax disputes, which are difficult to distinguish from general legislative and judicial costs (Allers, 1994, p. 19). In the reference literature, primarily due to the availability of data, most often administrative costs include direct expenses related to the maintenance of the tax administration (e.g. employee salaries, building maintenance costs, costs related to the purchase of fixed assets, IT systems, etc.).

The same applies to tax compliance costs. Also in this case there is no agreement as to which expenses should be included in this cost category. Their amount is shaped by both economic and non-economic factors. Tax compliance costs are typically high, 2 to 6 times higher than tax administrative costs. International comparisons show that they can amount to as much as $2.5 \%$ of GDP and are differentiated by the type of tax. At the same time, research has shown that the less complicated the tax system is and the more transparent the management of public levies collection, the lower the costs of fulfillment of tax obligations incurred by taxpayers (Torgler, 2005, pp. 133-157; Torgler \& Schneider, 2007; Cummings et al, 2005).

\section{A brief overview of studies on tax collection costs}

One of the first researchers to draw attention to the issue of the tax collection costs was Smith. The tax rules laid down by him, which set the classic tax pattern, also apply to the costs of functioning of the tax system, including those incurred by taxpayers. Smith (2007, p. 502 et seq.) distinguishes active (consisting in taking active measures to reduce the amount of taxes paid, which nowadays takes place e.g. in the case of employing a tax advisor) and passive (related to the settlement of tax liabilities resulting from legal acts) tax compliance costs. However, he indicates the need to reduce expenditures for fiscal administration by formulating the cheapness rule.

Detailed research on 'operating costs' related to tax collection did not begin until the 20th century, with the majority of papers on the subject being published in the last 30-35 years. According to Evans (2001), research on tax collection costs has been intensified since 1980. Initially, researchers paid more attention to administrative costs, relevant especially from the point of view of the state and maximization of tax revenue, and at the same time easier to estimate. As views on this matter evolved, it became evident that also the costs related to the adjustment of taxpayers to the requirements of the applicable tax system may have a significant impact on the amount of budget revenue and so- 
cial welfare (Kudła, 2004, p. 24). Tax compliance costs were first estimated by Haig (1935, pp. 323-333) in 1935, based on surveys conducted in 1500 American companies. He noted that administrative costs can be inversely proportional to the costs of adjustment; an increase in the costs of one category may or may not cause a decrease in the other.

Sandford et al. (1989, pp. 27-34) distinguish three major periods of research on the identification and measurement of operating costs, i.e. the North American period from 1930 to 1960; the European period of 1960-1970 and the worldwide period since 1980. In the years 1930-1960, based on the research conducted by North American scientists, a number of estimation methods were developed and the relationships between administrative costs and tax compliance costs were identified (e.g. regressive nature of tax compliance costs, interchangeability between compliance and administrative costs, etc. $)^{9}$.

In Europe, special attention was not paid to tax collection costs until the second half of the 20th century. However, the research only included selected jurisdictions, e.g. Great Britain, Germany, Ireland, Holland, Sweden ${ }^{10}$. After $1990^{11}$, a number of works on tax collection costs in Australia, New Zealand and Asia were published ${ }^{12}$. After 2000, research focused primarily on tax compliance costs, particularly in the context of enterprises, and to a lesser extent the researchers' attention was focused on the tax collection administrative costs. Detailed research on this cost category has been conducted since 2005 by the OECD.

\section{Tax collection administrative costs as one of the criteria of tax effectiveness in Poland}

Tax effectiveness (also referred to as fiscal effectiveness) is primarily related to the performance of the fiscal function of taxes; it can be simply explained as the efficiency of the tax system or individual taxes. It can be defined as the ratio of taxes paid (gross tax revenue) and basic economic values that can be treated as outlays and at the same time can determine the generation of tax revenues (Kulawczuk, 2004, p. 70). Tax effectiveness can also be considered in a broader

9 E.g. the research of Edelmann (1949); Oster, Lynn (1955); Yocum (1961); Johnston (1963) May, Thompson (1950); Bryden (1961); Wicks (1965 and 1966). More in Evans (2001).

10 E.g. Sandford et al.(1989); Allers (1994); Diaz \& Delgado (1995); Collard \& Godwin (1999); Hasseldine \& Hansford (2002).

${ }^{11}$ Before 1990 there were no published studies on operating costs in Australia and South-East Asia (Evans, 2001).

12 The most important are: Pope, Fayle, Duncanson 1990; Pope, Fayle, Chen 1991; Pope 1992; Pope, Fayle, Chen 1993,1994; Wallschutzky, Gibson, 1993; Evans, Ritchie, Tran-Nam, Walpole 1996,1997; Rametse, Pope 2002; Tran-Nam, Glover 2002, Sandford, Hasseldine 1992; Prebble 1995, Ariff, Loh, Talib 1995; Ariff, Ismail, Loh, 1997, Loh, Ismail, Shamsher, Ali 1997; Chan, Cheung, Ariff, Loh, 1999 (more in Evans (2001)). 
context, and then it will relate to all tax revenues, or a narrow one, in relation to individual taxes (e.g. personal income tax, VAT). This indicator is of technical nature and usually shows how many tax units have been obtained from a given source or from all taxes in a given period ${ }^{13}$. Fiscal effectiveness takes into account '(...) not only the amount of tax revenue that covers a significant part of public expenditure, which is most often attributed to its efficiency, but also stresses the requirement of the low cost of its collection, incurred by taxpayers and withholding agents, as well as tax administration' (Małecka-Ziembińska, 2012, p. 62). According to Małecka-Ziembińska, only a summary of the revenue and cost side can be used as a basis for assessing the fiscal effectiveness of a tax system or tax.

One of the measures of fiscal effectiveness may be the tax collection administrative costs, on the basis of which the effectiveness of a particular tax administration and, basically, of a government in the field of collection of public levies may be assessed. They allow for the assessment of the fiscal effectiveness of a given tax system or tax from the point of view of costs directly incurred by the public sector. In this case the measure of this effectiveness is the ratio of the costs incurred by tax administrations in connection with tax collection, and the net tax revenue collected in a given time (that is, not including the taxpayers' debt). The lower the ratio, the higher the tax effectiveness and lower administrative costs, and more effective tax administration in the country. In addition, when assessing the effectiveness, the amount of unpaid tax (tax debt) or actually their share in tax revenue is taken into account.

From a theoretical point of view, the calculation of tax collection administrative costs should not be too difficult. In practice, however, the lack of a clear definition of this category (as mentioned above), the determination of types of expenditures which fall within its scope and the lack of statistical data on particular types of expenditures are problematic. In this study, aggregated OECD data was used to assess fiscal effectiveness ${ }^{14}$.

Outlays on fiscal administration in Poland amounted to $1.6 \%$ of total tax revenue in 2013, which made up for $0.213 \%$ of GDP. In relation to 2005 , these outlays dropped by 0.34 pp in Poland. In Germany, this index was $1.35 \%(0.275 \%$ of GDP), in the Czech Republic 1.31\% (0.197\% of GDP), and in the UK $0.73 \%$ (0.213\% of GDP). EU's lowest indexes are recorded in Sweden $(0.39 \%, 0.164 \%$ of GDP), Estonia $(0.40 \%, 0.139 \%$ of GDP), Denmark $(0.48 \%, 0.226 \%$ of GDP) and Austria $(0.67 \%, 0.157 \%$ of GDP). On the basis of the OECD data analyzed, it can be stated that in order to maintain itself, the tax administration in Poland spends relatively the largest share of collected taxes among all EU countries. It

13 More in Dziemianowicz (2007).

${ }^{14}$ Given the differences in the structure of tax law and the organization of tax administrations in each country, international comparisons of tax effectiveness or tax administration efficiency should be made with great caution. At the same time, however, the data published by the OECD are the only such extensive set of information on tax collection costs incurred directly by the public sector. 
is also one of the most expensive in the world. Among 56 countries surveyed it ranked third in terms of incurred costs, after Japan and Saudi Arabia, where this index in 2013 was $1.74 \%$ (0.148\% of GDP) and 1.62\% (0.015\% of GDP), respectively.

In most of the countries surveyed in 2008-2013, public tax collection costs have dropped, but in Poland they increased by $0.01 \mathrm{pp}$. At the same time, it may be worrying that they increased by $0.05 \mathrm{pp}$ in relation to 2012, although in 2010-2012, after a sharp increase in 2009, which was a result of the crisis and decrease in tax revenues, they gradually started to drop (table 1).

Based on the data in table l, it can be stated that fiscal effectiveness in Poland, measured by the relation of administrative collection costs and tax revenues, is relatively low. However, it should be noted that the usefulness of this index, especially in assessing the effectiveness of tax administration in the analyzed countries, is limited, as this indicator does not allow for potential tax revenues, such as the VAT gap. As a result, it may turn out that countries with a similar fiscal effectiveness ratio are extremely different in terms of tax administration effectiveness. At the same time, specific solutions of a tax system structure and organization of a tax administration in a given country may affect the value of this indicator.

However, the effectiveness of fiscal administration may be indirectly assessed on the basis of the share of tax debt (including debt subject to enforcement proceedings) in net tax revenue. In 2013, this index amounted to $16.4 \%$ in Poland and increased by $3.2 \mathrm{pp}$ compared to 2012. This is one of the highest indexes in the EU. Higher ones are only noted in Hungary (21.8\%, fiscal effectiveness index $-1.15 \%$ ), Belgium (23.4\%, fiscal effectiveness index $-1.17 \%)$, Portugal (31.7\%, fiscal effectiveness index - 0.99\%), Greece (132.7\%, fiscal effectiveness index — data not available) and Italy (257\%, fiscal effectiveness index $1.05 \%)$. The average value of this index in the OECD countries in 2011-2013 was $22-24 \%$. The exceptionally high taxpayer debt in Greece and Italy (table 2) significantly affected the average value of the index.

Tax collection administrative costs vary from country to country. They significantly differ, for example, in the amount of IT spending that can be expected to contribute to the increase of tax administration effectiveness but also to the reduction in tax collection operating costs. The OECD data shows that countries with higher IT spending also have higher tax effectiveness indexes and are more efficient at tax administration (table 3). At the same time, however, it should be noted that the five OECD countries that had the lowest IT spending in 2013 had a lower fiscal administration effectiveness index (measured by the ratio of tax debt to net tax revenues), although this value was usually lower than the OECD average.

The poor assessment of the effectiveness of the Polish fiscal administration is also confirmed by the Data of the Ministry of Finance on systematical increase of tax debt which, as of the end of 2015, amounted to approx. PLN 59 billion and were over 78\% higher compared to 2013 and approx. 209\% higher 
compared to 2009. The greatest debtors are VAT taxpayers (chart 1). In recent years, the number of taxpayers who owe more than PLN 1 million to the state treasury is also increasing (NIK, 2016). At the end of 2014, the arrears due from taxpayers with a debt of over PLN 1 million accounted for 75.7\% (over PLN 31 billion) of the total tax debt. As of June 30, 2015, this ratio was 76.8\% (over PLN 37 billion). All this has a significant impact on the effectiveness of the Polish tax system, which is low, and the condition of the public finances.

The tax collection administrative costs are further increased by the complex and unstable tax system, which is likely to lower its fiscal effectiveness. This is mainly due to the complexity of the Polish tax system, which is governed by 11 acts and 292 regulations. Tax provisions in Poland are written down on over 5.7 thousand typescript pages, of which 2.7 thousand are regulations on personal income tax (Grant Thornton, 2017). Deeds related to individual taxes are complex, as evidenced by the number of individual tax interpretations issued, which is gradually increasing year by year. In 2015 as many as 38 thousand were issued. The variability of tax regulations is also a significant problem here. From the early 1990s, PIT, CIT and VAT acts were amended as many as 139 times. Unfortunately, there are indications that tax compliance costs, the hidden tax collection costs borne by the private sector and taxpayers, are also very high in Poland for the aforementioned reason. Taking into account the quoted studies, tax compliance costs may be 2 to 6 times higher than tax administrative costs, which may have a significant impact on the fiscal effectiveness of Polish taxes. This means that not only the administration needs reforming but, above all, the tax system requires simplification.

\section{Conclusion}

The considerations contained in this article prove that the tax collection costs are an important criterion for assessing the fiscal effectiveness of a tax system. They significantly affect the final level of tax revenue and should not be overlooked in economic analysis. The presentation of only tax revenues in the budget revenues, without clearly showing how much tax collection costs and how effective it is, creates an illusion of acquiring a high revenue from this source. In extreme cases, it may turn out that the costs are so high that the waiver of a tax title is a much cheaper option.

The tax collection administrative costs in Poland are high, one of the highest among the OECD countries, and the highest in the EU. This does not mean, however, that the Polish tax administration is effective. The assessment of its effectiveness is rather low, as evidenced by the data on tax debt due that rises year by year, or the increasing number of debtors owing more than PLN 1 million to the state treasury. In addition, the low efficiency of the Polish tax administration is reflected in the growing VAT gap, one of the largest in Europe. Unfortunately, all this have a negative effect on the fiscal effectiveness of the Polish 
tax system. Tax collection in Poland is too costly and, therefore, it should be considered how to increase its effectiveness at a given level of revenue.

Perhaps these costs will be reduced by the tax administration reform (KAS), which is expected to take effect from March 2017. Unfortunately, in the explanatory memorandum to the bill, the legislator does not provide any detailed calculations, giving only very general statements. However, taking into account the legal complexity of the Polish tax system and its variability, measures aimed only at changing the organization of the tax administration, even leading to a reduction in its operating costs, may be insufficient. The complex and variable tax system additionally increases the costs. Although the complexity of tax structures in legal terms does not always have to be unequivocal with the high cost of tax collection, there are strong indications that this is the case here. This means that work needs to be done as soon as possible, aimed at simplifying the Polish tax system.

\section{References}

Allers, M. (1994). Administrative and compliance costs of taxation and public transfers in the Netherlands. Groningen: Wolters-Noordhoff.

Ballard, C.L., Shoven, J.K. \& Whalley, J.B. (1985). General equilibrium computations of the marginal costs of taxes in the United States. American Economic Review, 75(1).

Collard, D., \& Godwin, M. (1999). The tax compliance costs for employers: UK PAYE and national insurance. 1995-96. Fiscal Studies, 20(4). doi:10.1111/j.1475-5890.1999.tb00020.x.

Cummings, R.G., Martinez-Vazquez, J., McKee, M., \& Torgler, B. (2005). Effects of tax morale on tax compliance: experimental and survey evidence. Leitner Program Working Paper, 22.

Diaz, C., \& Delgado, M. (1995). The compliance costs of personal income tax in Spain. In C. Sandford (Ed.), Taxation compliance costs measurement and policy. Bath: Fiscal Publications.

Dziemianowicz, R. (2007). Efektywność systemu opodatkowania rolnictwa. Białystok: Wydawnictwo Uniwersytetu w Białymstoku.

Evans, C. (2001). The operating costs of taxation: a review of the research. Economic Affairs, 21(2). doi:10.1111/1468-0270.00286.

Evans, C., \& Tran-Nam, B. (2014). Tax compliance costs in New Zealand: an international comparative evaluation. Tax Administration for the 21st Century Working Papers, 02.

Glapiński, A. (2003). Teoria kryzysu państwa podatków Josepha A. Schumpetera. Ekonomista, 1.

Grądalski, F. (2006). System podatkowy w świetle teorii optymalnego opodatkowania. Warszawa: Szkoła Główna Handlowa w Warszawie.

Grant Thornton. (2017). Podatki w Polsce. Retrieved 06.02.2017. from http:// grantthornton.pl. 
Gruszewska, E. (2012). Transformacja instytucji nieformalnych w Polsce, Gospodarka Narodowa, 3(247).

Haig, R. (1935). The cost to business concerns of compliance with tax laws. Management Review, 24.

Hasseldine, J., \& Hansford, A. (2002). The compliance burden of the VAT: further evidence from the UK. Australian Tax Forum, 17(4).

Hockuba, Z. (1995). Droga do spontanicznego porządku. Warszawa: PWN.

Kudła, J. (2004). Ekonomiczne problemy kosztów opodatkowania i nielegalnego unikania podatków. Warszawa: Uniwersytet Warszawski Wydział Nauk Ekonomicznych.

Kulawczuk, P. (2004). Efektywność podatkowa matych i średnich przedsiębiorstw. Gdańsk: Wydawnictwo Uniwersytetu Gdańskiego.

Małecka-Ziembińska, E. (2012). Efektywność fiskalna podatku dochodowego od osób fizycznych w Polsce. Poznań: Uniwersytet Ekonomiczny w Poznaniu.

NIK. (2016). Przedawnianie się zobowiąań podatkowych. Informacja o wynikach kontroli. Retrieved 06.02.2017 from https://www.nik.gov.pl.

OECD. (2015). Tax administration 2015: comparative information on OECD and other advanced and emerging economies. doi:10.1787/tax_admin-2015-en.

Olivier, T, \& Bartley, S. (2005). Tax system complexity and compliance costs some theoretical considerations. Economic Roundup, Winter.

Pedersen, H.S., Moerup, C., Andersen, C., Findsen, L., Nielsen, J.R., \& Lang, T.C. (2013). A review and evaluation of methodologies to calculate tax compliance costs. Taxation papers. Working Paper, 40. doi:10.2778/31058.

Robson, A. (2005). The costs of taxation. St Leonards: Centre for Independent Studies.

Sandford, C., Godwin, M., \& Hardwick, P. (1989). Administrative and compliance costs of taxation. Bath: Fiscal Publications.

Słownik Języka Polskiego. (2017). Retrieved 11.01.2017 ftom http://sjp.pwn.pl.

Smith, A. (2007). Badania nad naturą i przyczynami bogactwa narodów. Tom 2. Warszawa: PWN.

Torgler, B. (2005). Tax morale in Latin America. Public Choice, 122(1). doi:10.1007/s11127-005-5790-4.

Torgler, B., \& Schneider, F. (2007). The impact of tax morale and institutional quality on the shadow economy. IZA Discussion Paper, 2541.

Williamson, O.E. (1998). Ekonomiczne instytucje kapitalizmu. Firmy, rynki, relacje kontraktowe. Warszawa: PWN.

Zbroińska, B. (2009). Publiczne koszty transakcyjne instytucji systemu podatkowego. Gospodarka Narodowa, 11-12.

Zbroińska, B. (2011). Koszty transakcyjne skarbowości. Analiza instytucjonalna kontraktów skarbowych. Kielce: Wydawnictwo Uniwersytetu Jana Kochanowskiego.

Zbroińska, B. (2013). Wkład ekonomii kosztów transakcyjnych i teorii kontraktów do nauki o zarządzaniu. Studia i Materiaty. Miscellanea Oeconomicae, $17(2)$. 


\section{Acknowledgements}

Author contributions: author has given an approval to the final version of the article.

Funding: this research was fully funded by the University of Bialystok, Faculty of Economics and Management, Department of Treasury statutory sources. 


\section{Appendix}

Table 1 .

Cost of collection ratios in OECD (administrative costs/net revenue collections in \%)

\begin{tabular}{|c|c|c|c|c|c|c|c|c|c|}
\hline Country & 2005 & 2006 & 2007 & 2008 & 2009 & 2010 & 2011 & 2012 & 2013 \\
\hline Australia & 1.04 & 0.99 & 0.93 & 0.95 & 1.00 & 1.05 & 0.99 & 0.98 & 0.93 \\
\hline Austria $^{\mathrm{a}}$ & 0.66 & 0.66 & 0.64 & 0.79 & 0.85 & 0.70 & 0.66 & 0.68 & 0.67 \\
\hline Belgium $^{\mathrm{a}}$ & 1.43 & 1.57 & 1.39 & 1.27 & 1.40 & 1.29 & 1.36 & 1.23 & 1.17 \\
\hline Canada & 1.32 & 1.32 & 1.22 & 1.13 & 1.31 & 1.36 & 1.31 & 1.24 & 1.15 \\
\hline Chile & 0.69 & 0.63 & 0.60 & 0.67 & 0.91 & 0.77 & 0.68 & 0.67 & 0.66 \\
\hline Czechiab $^{\mathrm{b}}$ & 1.29 & 1.38 & - & 1.18 & 1.46 & 1.27 & 1.34 & 1.34 & 1.31 \\
\hline Denmark & 0.69 & - & 0.61 & 0.64 & 0.67 & - & - & 0.56 & 0.48 \\
\hline Estonia & 1.02 & 0.88 & 0.86 & 0.38 & 0.40 & 0.35 & 0.34 & 0.37 & 0.40 \\
\hline Finland ${ }^{c}$ & 0.78 & 0.79 & 0.77 & 0.80 & 0.88 & 0.84 & 0.80 & 0.79 & 0.75 \\
\hline France $^{b}$ & 1.08 & 1.28 & 0.96 & 1.17 & 1.31 & 1.25 & 1.20 & 1.19 & 1.11 \\
\hline Germany $^{\mathrm{b}}$ & 1.66 & 1.55 & 1.38 & 1.36 & 1.46 & 1.50 & 1.40 & 1.34 & 1.35 \\
\hline Greece & - & - & - & - & - & - & - & - & - \\
\hline Hungary & 0.99 & 1.11 & 1.15 & 1.17 & 1.20 & 1.20 & 1.12 & 1.13 & 1.15 \\
\hline Iceland ${ }^{c}$ & - & - & - & - & - & 0.62 & 0.60 & - & - \\
\hline Ireland & 0.82 & 0.78 & 0.79 & 0.95 & 1.08 & 1.26 & 1.14 & 0.87 & 0.85 \\
\hline Israel $^{a}$ & - & - & - & 0.74 & 0.79 & 0.75 & 0.68 & 0.94 & 0.94 \\
\hline Italy & - & - & - & 1.08 & 1.20 & 0.89 & 0.83 & 0.89 & 1.05 \\
\hline Japan $^{\mathrm{a}}$ & 1.65 & 1.52 & 1.50 & 1.49 & 1.71 & 1.93 & 1.75 & 1.84 & 1.74 \\
\hline Korea $^{\mathrm{a}}$ & 0.80 & 0.78 & 0.70 & 0.79 & 0.84 & 0.81 & 0.76 & 0.70 & 0.74 \\
\hline Luxemburg $^{\mathrm{b}}$ & - & - & 1.17 & 1.01 & 1.13 & 0.85 & 0.85 & 0.95 & 0.93 \\
\hline Mexico $^{\mathrm{a}}$ & 1.01 & 0.89 & 0.81 & 0.75 & 0.84 & 0.71 & 0.70 & 0.70 & 0.69 \\
\hline Netherlands & 1.36 & 1.14 & 1.12 & 0.99 & 1.11 & 1.02 & 0.97 & 0.94 & 0.95 \\
\hline New Zealand ${ }^{c}$ & 0.76 & 0.71 & 0.75 & 0.76 & 0.88 & 0.81 & 0.89 & 0.92 & 0.85 \\
\hline Norway $^{c}$ & - & 0.58 & 0.53 & 0.54 & 0.50 & 0.56 & 0.55 & 0.43 & 0.41 \\
\hline Poland ${ }^{\mathrm{b}}$ & 1.94 & 1.75 & 1.42 & 1.59 & 1.72 & 1.91 & 1.69 & 1.55 & 1.60 \\
\hline Portugala $^{\mathrm{a}}$ & 1.34 & 1.22 & 1.18 & 1.27 & 1.57 & 1.55 & 1.37 & 0.94 & 0.99 \\
\hline Slovakia $^{a}$ & 2.20 & 2.49 & 2.41 & - & - & 3.06 & 3.04 & 1.36 & 1.43 \\
\hline Slovenia $^{c}$ & 0.95 & 0.97 & 0.84 & 0.81 & 0.90 & 0.96 & 0.93 & 0.91 & 0.89 \\
\hline Spain $^{\mathrm{a}}$ & 0.74 & 0.68 & 0.64 & 0.82 & 0.97 & 0.88 & 0.86 & 0.66 & 0.67 \\
\hline Sweden & - & - & - & 0.39 & 0.40 & 0.41 & 0.40 & 0.39 & 0.39 \\
\hline Switzerland & - & - & - & 0.45 & 0.46 & 0.37 & 0.38 & 0.30 & 0.29 \\
\hline Turkey $^{a}$ & 0.87 & 0.84 & 0.83 & 0.85 & 0.93 & 0.78 & 0.76 & 0.78 & 0.64 \\
\hline UK & 1.10 & 1.09 & 1.11 & 0.90 & 0.91 & 0.98 & 0.83 & 0.74 & 0.73 \\
\hline United States & 0.52 & 0.48 & 0.45 & 0.49 & 0.61 & 0.66 & 0.62 & 0.56 & 0.47 \\
\hline
\end{tabular}

Note:

${ }^{\text {a }} \mathrm{SSC}$ not include

bSC and excises not included

${ }^{c}$ Excises not included

Source: Own preparation based on OECD (2015, p. 181). 
Table 2.

Total year-end tax debt (including disputed debt)/net revenue collections for fiscal year (in \%)

\begin{tabular}{|c|c|c|c|}
\hline Country & 2011 & 2012 & 2013 \\
\hline Australia & 10.1 & 10.5 & 10.7 \\
\hline Austria & 8.5 & 8.5 & 9.0 \\
\hline Belgium & 24.6 & 24.1 & 23.4 \\
\hline Canada & 12.7 & 12.3 & 12.5 \\
\hline Chile & - & - & - \\
\hline Czechia & - & - & - \\
\hline Denmark & 7.4 & 7.2 & 6.5 \\
\hline Estonia & 7.5 & 5.8 & 4.4 \\
\hline Finland & 8.0 & 8.2 & 7.4 \\
\hline France & 9.6 & 11.1 & 10.9 \\
\hline Germany & 3.3 & 3.2 & - \\
\hline Greece & 103.5 & 115.7 & 132.7 \\
\hline Hungary & 23.0 & 21.7 & 21.8 \\
\hline Iceland & 24.2 & - & - \\
\hline Ireland & 5.8 & 4.6 & 4.0 \\
\hline Israel & 14.3 & 10.1 & 9.0 \\
\hline Italy & 207.8 & 229.5 & 257.0 \\
\hline Japan & 3.7 & 3.5 & 3.1 \\
\hline Korea & 3.0 & 3.1 & 3.4 \\
\hline Luxemburg & 14.6 & 15.8 & 15.0 \\
\hline Mexico & 52.5 & 44.3 & 31.5 \\
\hline Netherlands & 7.7 & 6.9 & 6.6 \\
\hline New Zealand & 10.3 & 10.3 & 9.2 \\
\hline Norway & 3.7 & 3.0 & 3.1 \\
\hline Poland & - & 13.2 & 16.4 \\
\hline Portugal & 39.0 & 35.7 & 31.7 \\
\hline Slovakia & - & - & - \\
\hline Slovenia & 13.3 & 14.7 & 14.0 \\
\hline Spain & 11.7 & 13.2 & 13.9 \\
\hline Sweden & 2.2 & 2.3 & 2.5 \\
\hline Switzerland & 2.5 & 1.9 & 1.8 \\
\hline Turkey & - & - & - \\
\hline United Kingdom & 7.4 & 6.7 & 6.5 \\
\hline United States & 14.4 & 13.0 & 11.0 \\
\hline
\end{tabular}

Source: Own preparation based on OECD (2015, p. 231). 
Table 3.

Expenditures on IT and salaries (including IT-related) vs. the fiscal effectiveness index in selected OECD countries in 2013 (in \%)

\begin{tabular}{lccccc}
\hline \multirow{2}{*}{ Country } & \multicolumn{2}{c}{$\begin{array}{c}\text { Percent of total } \\
\text { costs in } 2013\end{array}$} & $\begin{array}{c}\text { Total administrative } \\
\text { costs/net revenue }\end{array}$ & $\begin{array}{c}\text { Total administrative } \\
\text { costs/GDP }\end{array}$ & $\begin{array}{c}\text { Total year-end tax debt/net } \\
\text { revenue collections for fiscal year }\end{array}$ \\
\cline { 2 - 3 } Salary & IT & Countries with relatively low reported investments in IT \\
Belgium & 79.6 & 4.5 & 1.17 & 0.304 & 23.4 \\
France & 79.9 & 2.9 & 1.11 & 0.191 & 10.9 \\
Germany & 79.2 & 6.8 & 1.35 & 0.275 & $3.20^{\text {a }}$ \\
Luxemburg & 81.0 & 4.8 & 0.93 & 0.233 & 15.0 \\
Poland & 68.7 & 1.0 & 1.60 & 0.213 & 16.4 \\
& & Countries with relatively high reported investments in IT & \\
Austria & 86.3 & 26.8 & 0.67 & 0.157 & 9.0 \\
Denmark & 60.9 & 16.9 & 0.48 & 0.226 & 6.5 \\
Finland & 64.8 & 26.8 & 0.75 & 0.197 & 2.5 \\
Sweden & 70.1 & 19.5 & 0.39 & 0.164 & 6.5 \\
UK & 58.0 & 21.3 & 0.73 & 0.213 & 7.4 \\
\hline
\end{tabular}

Note:

a - 2012 data

Source: Own preparation based on OECD (2015).

Scheme 1 .

A breakdown of tax transaction costs

\begin{tabular}{|c|c|c|c|c|}
\hline \multirow{6}{*}{ 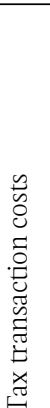 } & \multirow{5}{*}{$\begin{array}{c}\text { Tax collection } \\
\text { costs }\end{array}$} & \multirow{4}{*}{$\begin{array}{l}\text { Tax compliance } \\
\text { costs }\end{array}$} & \multirow{2}{*}{ Monatary } & Mandatory \\
\hline & & & & Voluntary \\
\hline & & & \multirow{2}{*}{ Non-monatary } & Mandatory \\
\hline & & & & Voluntary \\
\hline & & \multicolumn{3}{|c|}{ Tax administrative costs } \\
\hline & & Excess b & n of taxation & \\
\hline
\end{tabular}

Source: Own preparation based on Olivier \& Bartley (2005, p. 55). 
Chart 1.

Total year-end tax debt and tax debt VAT in Poland (in mln PLN)

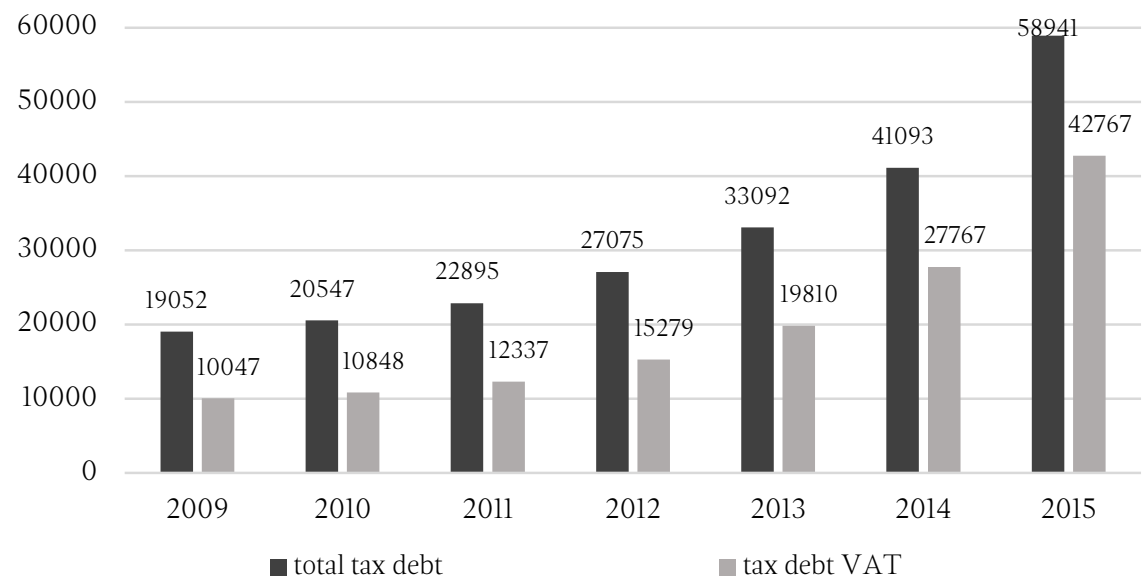

Source: Own preparation based on NIK (2016, p.20). 